\title{
Digital Teaching Material in Learning Content of Rewanda Traditional Value in Goa Kreo Semarang to Improve Historical Awareness of Students atSMA Negeri
}

\section{Rian Agus Mulyawan, Leo Agung, Djono}

Universitas Sebelas Maret

rianagusmulyawan07@gmail.com

\section{Article History}

accepted 1/09/2020

approved 4/10/2020

published 1/12/2020

\begin{abstract}
:
The purpose of this study is to explain the process of cultivating historical awareness of the value of the rewanda custom in the cave creo semarang in history learning at SMA Negeri 12 Semarang, explaining how historical awareness among students at SMA Negeri 12 Semarang, explains the relevance between Adat Rewanda and Historical Awareness in learning and explaining how to integrate the traditional values of rewanda in Goa Kreo Semarang with history learning at SMA Negeri 12 Semarang. Researchers used qualitative research methods with descriptive and phenomenological approaches. The results of this study indicate that the cultivation of historical awareness of the customary value of rewanda in the cave creo semarang is appropriate, proven by the existence of a Learning Implementation Plan and Syllabus in the 2013 Curriculum, the implementation of learning, evaluation and historical awareness of students which is shown mostly from the results of student interviews, namely understanding. There are factors that affect the level of students' historical awareness, among others, the history of teacher competence, existing learning, and the environment. The facilities used in the cultivation of historical awareness are supported by learning and extracurricular resources.
\end{abstract}

Keywords: Teaching materials, traditional rewanda, historical awareness

\begin{abstract}
Abstrak:
Tujuan dari penelitian ini yaitu menjelaskan proses penanaman kesadaran sejarah terhadap nilai dari adat rewanda di goa kreo semarang dalam pembelajaran sejarah di SMA Negeri 12 Semarang, menjelaskan bagaimana kesadaran sejarah pada siswa di SMA Negeri 12 Semarang, menjelaskan relevansi antara Adat Rewanda dan Kesadaran Sejarah dalam pembelajaran dan menjelaskan bagaimana pengintregrasian nilai-nilai Adat rewanda di Goa Kreo Semarang dengan pembelajaran Sejarah di SMA Negeri 12 Semarang. Peneliti menggunakan metode penelitian kualitatif dengan pendekatan deskriptif dan fenomenologi. Hasil penelitian ini menunjukkan bahwa penanaman kesadaran sejarah terhadap nilai adat rewanda di goa kreo semarang sudah sesuai dibuktikan adanya Rencana Pelaksanaan Pembelajaran dan Silabus pada Kurikulum 2013, pelaksanaan pembelajaran, evaluasi dan kesadaran sejarah siswa yang ditunjukkan sebagian besar dari hasil wawancara siswa yaitu paham. Adanya faktor-faktor yang mempengaruhi tingkat kesadaran sejarah siswa antara lain dari kompetensi guru sejarah, pembelajaran yang ada, dan lingkungannya. Fasilitas yang digunakan dalam penanaman kesadaran sejarah sudah mewadahi ditunjang dari sumber belajar dan ekstrakulikuler.
\end{abstract}

Kata Kunci: Bahan ajar, adat rewanda, kesadaran sejarah

Social, Humanities, and Education Studies (SHEs): Conference Series https://jurnal.uns.ac.id/shes

p-ISSN 2620-9284

e-ISSN 2620-9292 


\section{PENDAHULUAN}

Sejarah harus dipelajari sejak dini oleh setiap orang sebagai bentuk hubungan antara individu dengan masyarakat atau bangsa. Hubungan tersebut memerlukan terbentuknya kesadaran terpentingnya sejarah dalam persoalan kehidupan bersama seperti solidaritas dan nasionalisme. Dalam suatu kelompok masyarakat atau bangsa pasti memiliki cita-cita, demi terwujudnya cita-cita ini sangat ditentukan oleh generasi muda. Untuk itulah penerus bangsa ini harus mampu memahami sejarah bangsa khususnya kebudayaan generasi muda tersebut, khususnya pendidikan sejarah yang menjadi sarana kongkrit untuk menumbuhkan pemahaman pentingnya sejarah

Sejarah Daerah maupun kebudayaan lokal mempunyai fungsi untuk memperkuat sejarah nasional melalui penjabaran dan mengangkat peran daerah dalam konstelasi nasional. Baik sejarah nasional maupun sejarah daerah bersifat ideologis politik, dan tidak mempunyai batasan ilmiah yang selalu bisa dipertahankan secara akademis. Sebab batasan tersebut sewaktu- waktu bisa berubah sesuai dengan perkembangan politik nasional. Sering terjadi, dalam penulisan sebagai 'sejarah bangsa indonesia' yang eksistensi politisnya resmi sejak sejarah daerah selalu menonjolkan kasus-kasus yang mempunyai relevansi dengan sejarah nasional. Sebagai contoh, penulisan sejarah daerah dengan mencari kasus-kasus yang berhubungan dengan peranan daerah tersebut dalam kebangkitan nasional, sumpah pemuda, proklamasi kemerdekaan, dan sebagainya. Akibatnya, pembelajaran sejarah terasa kering dan membosankan, karena indoktrinatif dan bersifat trickle down. Hal ini juga dibenarkan oleh Mastrianto (2020:4) yang mengatakan bahwa sejarah lokal begitu penting bagi kehidupan masyarakat terutama masyarakat modern saat ini. Pada dasarnya mempelajari sejarah lokal sangat bermanfaat, yakni sebagai sumber kreativitas dan pandangan optimis masyarakat lokal. Terobosan ini bertujuan menggugah kesadaran dan perhatian insan pendidikan dalam menggali dan mengembangkan pendidikan yang berbasis budaya lokal yang bersumber dari potensi lokal. Pembelajaran sejarah berbasis nilai-nilai adat rewanda diharapkan mampu membangkitkan kesadaran sejarah yang selama ini termaretginalkan dan teralinasi dari perhatian publik. Hal ini menjadi isu aktual yang mendapat perhatian publik secara luas, sehingga masyarakat terpanggil untuk berpartisipasi aktif dalam proses kegiatan penelitian dan pengembangan kesadaran sejarah lokal. Dalam implementasinya pendidikan berbasis nilai-nilai adat rewanda ini bisa terintegrasi dalam mata pelajaran.

Kesadaran sejarah sangat penting dalam kehidupan masyarakat karena kesadaran sejarah merefleksikan jati diri bangsa. Menurut Kartodirdjo (1992: 248) "dalam rangka pembangunan bangsa, pengajaran sejarah tidak semata-mata berfungsi memberi pengetahuan sejarah sebagai kumpulan informasi fakta sejarah, tetapi juga bertujuan menyadarkan anak didik atau membangkitkan kesadaran kesejarahannya. Sejarah tidak boleh hanya dipahami sebagai sarana transfer of knowledge melainkan sekaligus media penyadaran sejarah." Zuhdi (2008: 290) menegaskan bahwa "fungsi sejarah sebagai materi yang substantif untuk nation and character building."

Dalam penelitian ini, akan diintegraskan nilai-nilai adat nguguh di Goa Kreo Semarang ke dalam pembelajaran Kebudayaan di kelas. Pembelajaran Sejarah kebudayaan tentang adat rewanda di Goa Kreo Semarang dapat dimanfaatkan sebagai media pembelajaran kebudayaan agar peserta didik tidak hanya mengetahui sejarah Indonesia secara umum, tetapi juga memahami kebudayaan lokal yang terjadi didaerahnya yang merupakan bagian dari sejarah yang ada di Indonesia.

Untuk memudahkan guru dalam penyampaian informasi tentang kebudayaan lokal yang ada di lingkungan peserta didik, dosen memanfaatkan nilai nilai dari kebudayaan adat rewanda yang ada di Goa Kreo Semarang Semarang sebagai bahan ajar kebudayaan lokal dalam menjelaskan nilai-nilai yang terkandung dalam adat rewanda. Dan juga menggunakan media adat rewanda ini dirasa lebih tepat dan efektif dalam membantu dosen menyampaikan informasi tentang salah satu budaya lokal yang ada di 
Semarang. Dengan mengembangkan bahan ajar yang memanfaatkan nilai-nilai filosofi yang terkandung dalam adat rewanda Semarang, mahasiswa memperoleh informasi secara menyeluruh tentang materi tersebut, yang nantinya diharapkan tercapainya tujuan pembelajaran yang diikuti untuk menghargai budaya lokal dan dapat melestarikannya tersebut. Hal ini merupakan faktor penting karena kesadaran budaya lokal dan budaya tradisi masyarakat merupakan sasaran yang harus dicapai dalam pembelajaran kebudayaan Semarang. Inilah alasan penulis melakukan penelitian

\section{METODE}

Metodologi yang dipakai dalam tulisan ini adalah metode kualitatif dengan analisis deskriptif. Bogdan dan Taylor (Moleong, 2002) mendefinisikan pendekatan kualitatif segabagi prosedur penelitian yang menghasilkan data deskriptif berupa kata kata tertulis atau lisan dari orang orang dan pelaku yang dapat diamati. Metode ini digunakan untuk mendeskripsikan penanaman kesadaran sejarah dalam pembelajaran sejarah lokal dengan menggunakan bahan ajar digital berupa ebook digital. Teknik pengumpulan data yang digunakan berupa studi kepustakaan, wawancara dan observasi partisipatoris. Wawancara mendalam dilakukan dengan pihak-pihak yang terkait sepereti kepala sekolah, guru mata pelajaran, dan siswa. Observasi yang yang dilakukan dalam penelitian ini dengan memperhatikan desain materi pembelajaran yang meliputi perencanaan, pelaksanaan, dan tindak lanjut pembelajaran. Observasi dilakukan dengan pengamatan langsung yang meliputi aspek kognitif seperti hasil ulangan, dan tugas tugas siswa, serta aspek psikomotorik yang diamati adalah perilaku siswa di sekolah.

\section{HASIL DAN PEMBAHASAN \\ Kesadaran sejarah pada siswa di SMA Negeri 12 Semarang}

Kesadaran merupakan penghayatan terhadap yang dilakukan secara sadar akan yang dialami (dilihat, didengar), dan sadar akan proses pengamatan itu sendiri yang bersifat athetis dan abstrak. Perhatian tidak terfokus pada objek pengamatan, tetapi juga terfokus pada persepsi terhadap objek (Kartodirjo, 1990). Secara harfiah, kesadaran itu berarti pemahaman terhadap sesuatu dengan melibatkan mental, yang menyangkut ide, perasaan, pemikiran, kehendak dan ingatan yang terdapat pada diri seseorang jika ia sedang memikirkan sesuatu yang ada disekitarnya. Sejarah secara sederhana dapat berarti peristiwa yang dapat ditimbulkan oleh aktivitas manusia dimasa lalu di suatu tempat tertentu. Kesadaran sejarah adalah refleksi sikap yang bersumber pada kondisi kejiwaan yang menunjukan tingkat penghayatan, pada makna serta hakikat sejarah (Widja, 1989:556).

Kesadaran sejarah pada manusia sangat penting artinya bagi pembinaan budaya bangsa. Kesadaran sejarah dalam konteks ini bukan hanya sekedar memperluas pengetahuan, melainkan harus diarahkan pula kepada kesadaran penghayatan nilainilai budaya yang relevan dengan usaha pengembangan kebudayaan itu sendiri. Kesadaran sejarah dalam konteks pembinaan budaya bangsa dalam pembangkitan kesadaran bahwa bangsa itu merupakan suatu kesatuan sosial yang terwujud melalui suatu proses sejarah, yang akhirnya mempersatukan sejumlah nasion kecil dalam suatu nasion besar yaitu bangsa.

Pembelajaran adalah proses interaksi siswa dengan guru dan juga sumber belajar pada suatu lingkungan belajar mengajar. Pembelajaran sejarah adalah perpaduan antara aktivitas belajar dan mengajar yang di dalamnya mempelajari tentang peristiwa pada masa lampau yang erat hubungannya dengan masa sekarang sehingga dapat diambil nilai-nilai yang terkandung di dalamnya. Dengan adanya kesadaran sejarah siswa pada kurikulum inilah siswa akan lebih mudah memahami materi pelajaran 
sejarah. Pembelajaran sejarah sangat berkaitan dengan penanaman kesadaran sejarah. Hal ini karena dalam esensi materi yang disampaikan terkandung nilai-nilai karakter di dalamnya. Pembelajaran sejarah terdiri dari beberapa tahapan. Tahapan-tahapan tersebut diantaranya: tahap perencanaan, pelaksanaan dan evaluasi, dan kesadaran sejarah. Sebelum mengetahui dalam tahapan pembelajaran sejarah, sekiranya mengetahui relevansi keterkaitan materi.

Menurut Pramono (2014:115) kemampuan guru sejarah dalam menyusun perencanaan, pengembangan perangkat, pengelolaan proses pembelajaran, menciptakan interaksi edukatif antara peserta didik dengan guru dan sumber belajar, serta alat evaluasi dan pelaksanaannya merupakan aspek-aspek penting untuk melihat kinerja guru.

\section{Relevansi antara Adat Rewanda dan Kesadaran Sejarah dalam pembelajaran}

Berdasarkan wawancara yang dilakukan oleh peneliti dapat disimpulkan bahwa adanya Kompetensi Inti (KI) dan Kompetensi Dasar (KD), juga ada keterkaitan materi Sejarah Tentang adat rewanda dan Kesadaran Sejarah dengan materi pembelajaran yang disampaikan oleh guru sejarah.

Rancangan Kegiatan Belajar Mengajar (KBM) mata pelajaran sejarah masa islam di Nusantara ditemukan sudah sesuai dengan tujuan pembelajaran sejarah yang telah dirumuskan, materi ini ditekankan untuk bisa menilai kesadaran sejarah. Guru merumuskan tujuan dalam pembelajaran sejarah berdasarkan pada panduan yang terdapat pada silabus mata pelajaran sejarah dalam Kurikulum 2013 tingkat SMA atau setara. Dalam Rencana Pelaksanaan Pembelajaran (RPP) juga disebutkan bahwa pedoman penilaian yang diterap-kan terdiri dari tiga aspek. Ketiga aspek itu yaituaspek pengetahuan, aspek sikap dan aspek keterampilan.

Pelaksanaan Pembelajaran Sejarah salah satu bagian yang terpenting peningkatan kualitas pendidikan adalah sistem pembelajaran. Pelaksanaan proses pembelajaran ini merupakan tanggung jawab guru dalam mengembangkan segala potensi yang ada pada siswa.

Dari hasil pengamatan yang dilakukan oleh peneliti, dapat diketahui bahwa cara pelaksanaan pembelajaran sejarah dalam memahamkan siswa tertarik dengan pembelajaran sejarah dengan terjun langsung di lokasi adat rewanda yang berada di goa kreo, Semarang. Hal ini didukung oleh model pembelajaran sejarah Islam di Nusantara yang diterapkan oleh guru. Salah satunya dengan pemberian materi dengan menggunakan metode karya wisata dan media tentang adat rewanda peninggalan sunan kalijaga pada masa Kerajaan Demak berkuasa. Dengan media ini siswa akan lebih tertarik memahami pelajaran. Materi-materi yang disampaikan oleh guru juga diambil dari berbagai sumber. Sumber-sumber tersebut diantaranya buku, internet, dan lain-lain. Buku-buku yang digunakan juga bervariasi. Buku yang digunakan ada buku guru dan buku siswa Sejarah Kebudayaan Islam Kelas XII Kurikulum 2103, dan LKS

Bagian terakhir dari pembelajaran sejarah adalah tahap evaluasi pembelajaran sejarah. Evaluasi pembelajaran sejarah Materi masuknya Islam ke Nusantara di SMA Negeri 12 Semarang dilakukan untuk mendapatkan informasi tentang hasil pembelajaran sejarah. Dengan demikian fokus evaluasi pembelajaran sejarah adalah pada hasil pemahaman siswa. Informasi hasil pembelajaran sejarah ini kemudian dibandingkan dengan tujuan pembelajaran sejarah yang telah dirumuskan. Jika hasil nyata pembelajaran sesuai dengan tujuan pembelajaran sejarah yang telah dirumuskan, maka pembelajaran dapat dikatakan efektif. Sebaliknya, jika hasil nyata pembelajaran tidak sesuai dengan tujuan pembelajaran sejarah yang telah dirumuskan, maka pembelajaran dikatakan kurang efektif.

Tubagus menggunakan beberapa model penilaian. Model-model penilaian tersebut merupakan penerapan dari rencana pembelajaran yang ada di dalam Rencana Pelaksanaan Pembelajaran (RPP). Model-model penilaian tersebut di-antaranya 
penilaian tertulis, penilaian tugas terstruktur dan penilaian sikap. Evaluasi pembelajaran sejarah Masuknya Islam ke Nusantar di SMA Negeri 12 Semrang sudah sesuai dalam Rencana pelaksanaan Pembelajaran dan silabus. Penilaian-penilaian tersebut sudah direncanakan dan dapat diaplikasikan dalam evaluasi pembelajaran sejarah Masuknya Islam ke Nusantara dan tergantung kebutuhan kelas. Model-model penilaian tersebut diantaranya penilaian tertulis, penilaian tugas terstruktur dan penilaian sikap.

Kesadaran sejarah terdapat tiga aspek kognitif, afektif dan psikomotorik. Dalam hal ini guru sejarah sudah berhasil menanamkan kesadaran sejarah terhadap Adat Rewanda di Goa Kreo, Semarang.

Penanaman kesadaran sejarah terhadap Adat Rewanda di Goa Kreo sudah efektif. Penerapan Kesadaran Sejarah juga dapat di dapat melalui pengembanganpengembangan media pembelajaran digital yang sesuai dengan perkembangan zaman (Syahputra, 2020: 162). Menurut Aman (2011:140) kesadaran sejarah tidak lain dari pada kondisi kejiwaan yang menunjukkan tingkat penghayatan pada makna dan hakikat sejarah bagi masa kini dan bagi masa yang akan datang, menyadari dasar pokok bagi berfungsinya makna sejarah dalam proses pendidikan. Kesadaran sejarah pada manusia sangat penting bagi pembinaan budaya bangsa. kesadaran sejarah tidak hanya pada menambah pengetahuan, namun juga menyadari bahwa perlu juga menghayati nilai-nilai budaya bangsa. Untuk mengenal identitas bangsa diperlukan pengetahuan sejarah pada umumnya dan sejarah nasional pada khususnya. Hal ini ditunjukkan pemahaman siswa SMA Negeri 12 Semarang yang baik dalam hasil pembelajaran.

\section{Pengintregrasian nilai-nilai Adat rewanda di Goa Kreo Semarang dengan pembelajaran Sejarah di SMA Negeri 12 Semarang}

Kegiatan belajar mengajar akan berkualitas jika didukung oleh guru professional yang memiliki kompetensi kompetensi yang sinkron dengan kemampuan. Guru sejarah bertanggung jawab menginterprestasikan konsep sejarah masuknya islam ke nusantar kepada siswa secara objektif dan sederhana. la harus menguasai subjek tersebut serta teknik-teknik pembelajaran yang digunakan dalam mengajar. Secara umum kompetensi guru terdiri atas kompetensi profesional, pedagogik, kepribadian dan sosial.

Berdasarkan wawancara siswa dan guru, peneliti menyimpulkan bahwa guru sejarah di SMA Negeri 12 Semarang sudah memiliki kompetensi-kompetensi yang diwajibkan sebagai seorang guru sejarah. Di antaranya kompetensi pedagogik, kompetensi kepribadian, kompetensi sosial, kompetensi profesional, dan kompetensi khusus sejarah. Diantaranya guru dapat merancang kegiatan pembelajaran yang sesuai dengan karakteristik peserta didik, mengidentifikasi karakteristik belajar setiap peserta didik di kelasnya, melakukan pengecekan secara rutin bahwa semua peserta didik secara aktif melaksanakan kegiatan pembelajaran yang diberikan, dan mencoba mengetahui penyebab penyimpangan perilaku siswa guna mencegah perilaku tersebut tidak merugikan peserta didik lainnya, dan guru juga memperhatikan siswa dengan kelemahan fisik tertentu agar dapat mengikuti aktivitas pembelajaran

Penanaman kesadaran sejarah dalam pembelajaran sejarah masuknya Islam ke nusantara didasarkan pada kurikulum 2013. Hal ini dengan adanya penanaman kesadaran sejarah terhadap nilai-nilai adat rewanda bagi siswa pada kurikulum 2013 yang menekankan peningkatan kesadaran sejarah melalui peninggalan sejarah, siswa akan lebih mudah memahami tujuan dari pembelajaran sejarah. Hal ini perlu juga adanya peran guru dalam menanamkan kesadaran sejarah terhadap nilai-nilai adat rewanda.

\section{SIMPULAN}

Berdasarkan hasil penelitian mengenai dapat ditarik beberapa kesimpulan bahwa penanaman kesadaran sejarah terhadap Nilai adat rewanda di goa kreo semarang 
dalam pembelajaran sejarah di SMA Negeri 12 Semarang sudah sesuai atas kaidah tertentu. Dalam pembelajaran sejarah berupa penanaman kesadaran sejarah terhadap Nilai adat rewanda ditujukan untuk membentuk kesadaran siswa akan pentingnya sejarah, dan dilihat dari pemahamannya terhadap nilai adat rewanda tampak pada pernyataan siswa ketika di wawancara yaitu sebagian besar siswa mengetahui. Kemudian, diperjelas dengan siswa mengatakan bahwa siswa juga sering berkunjung ke Goa kreo, bahkan beberapa masih ikut serta dalam melaksanakan adat rewanda di goa kreo.

Faktor-faktor yang mempengaruhi tingkat kesadaran sejarah siswa terhadap nilai adat rewanda di SMA Negeri 12 Semarang sudah cukup mendukung dalam menanamkan kesadaran sejarah pada siswa. faktor mempengaruhi tingkat kesadaran siswa berupa pembelajaran, lingkungan dan kompetensi yang dimiliki guru sejarah yaitu melalui kompetensi yang dimiliki guru. Hal ini di liat dari wawancara guru sejarah dan siswa di SMA Negeri 12 Semarang.

\section{DAFTAR PUSTAKA}

Aman. 2011. Model Evaluasi Pembelajaran Sejarah. Yogyakarta: Ombak.

Amboro, Kian. 2015.'Membangun Kesadaran Berawal dari Pemahaman; Relasi Pemahaman Sejarah dengan Kesadaran Se-jarah Mahasiswa Program Studi Pendidikan Sejarah FKIP Universitas Mu-hammadiyah Metro'. Jurnal Historia. 3 (2):111

Amin, Syaiful. 2011.'Pewarisan Nilai Sejarah Lokal Melalui Pembelajaran Sejarah Jalur Formal dan Informal Pada Siswa SMA Di Kudus Kulon'. Jurnal Paramita. 21 (1):113.

Kartodirdjo, Sartono. 1992. Pendekatan IImu Sosial dalam Metodologi Sejarah. Jakarta: PT. Gramedia Pustaka Utama.

Mastrianto, A. 2017. EFEKTIVITAS PENGGUNAAN MODEL PEMBELAJARAN TUTOR SEBAYA TERHADAP MINAT BELAJAR SISWA PADA MATA PELAJARAN SEJARAH KELAS XII IPS1 SMA NEGERI 17 BANDAR LAMPUNG TAHUN AJARAN 2016/2017.

Moleong, L. 2012. Metodologi penelitian kualitatif. PT. Remaja Rosdakarya

Pramono, Eko Suwito. 2014. 'Kinerja Guru Se-jarah: Studi Kausal pada Guru-guru Sejarah SMA di Kota Semarang'. Jurnal Paramita 24 (1):115.

Syahputra, M. A. D., \& Sariyatun, D. T. A. 2020. The Level Of Student's Historical Awareness In Historical Education Program As A Need Analysis Of Digital Learning Media Development. International Journal of Education and Social Science Research, 3(5), 162-172

Widja, I Gde. 1989. Sejarah Lokal dalam Prespektif Pendidikan. Jakarta: Depdikbud 